\title{
Anaerobic Codigestion of Slaughter Residues with Agricultural Waste of Amaranth Quinoa and Wheat
}

Orlando Washington Meneses Quelal

Universitat Politècnica de València: Universitat Politecnica de Valencia

Borja Velázquez Martí ( $\nabla$ borvemar@dmta.upv.es )

Universidad Politecnica de Valencia https://orcid.org/0000-0002-8157-0421

Juan Gaibor Chávez

Universidad Estatal de Bolívar: Universidad Estatal de Bolivar

\section{Zulay Niño Ruiz}

IKIAM: Universidad Regional Amazonica IKIAM

\section{Andrés Ferrer Gisbert}

Universitat Politècnica de València: Universitat Politecnica de Valencia

\section{Research Article}

Keywords: methane, co-digestion, slaughterhouse waste, agricultural waste, kinetics, biodegradability.

Posted Date: July 7th, 2021

DOI: https://doi.org/10.21203/rs.3.rs-223776/v2

License: (c) (1) This work is licensed under a Creative Commons Attribution 4.0 International License. Read Full License 


\title{
ANAEROBIC CODIGESTION OF SLAUGHTER RESIDUES WITH
} AGRICULTURAL WASTE OF AMARANTH QUINOA AND WHEAT

\author{
Orlando Washington Meneses-Quelal ${ }^{(1)}$, Borja Velázquez-Martí ${ }^{(1)}$ Juan Gaibor-Chávez ${ }^{(2)}$, \\ Zulay Niño-Ruiz ${ }^{(3)}$, Andrés Ferrer-Gisbert ${ }^{(1)}$
}

${ }^{1)}$ Departamento de Ingeniería Rural y Agroalimentaria. Universitat Politècnica de Valencia. Camino de Vera s/n, 46022 Valencia (España)

2) Departamento de Investigación, Centro de Investigación del Ambiente, Universidad Estatal de Bolívar, Guaranda, Ecuador

${ }^{3)}$ Laboratorio de Biomasa. Biomass to Resources Group. Universidad Regional Amazónica Ikiam. Vía Tena Muyuna Kilómetro 7, Tena, Napo, Ecuador

\section{Abstract}

The objective of this research is to experimentally evaluate the anaerobic co-digestion of slaughterhouse residues in the city of Guaranda with straw residues from agriculture, such as: amaranth, quinoa and wheat. The study was carried out on a laboratory scale using $311 \mathrm{ml}$ biodigesters under mesophilic conditions of $37^{\circ} \mathrm{C}$. Anaerobic co-digestion resulted in methane yields of $407 \mathrm{ml} \mathrm{CH}_{4} / \mathrm{g}$ VS, with a methane content in the biogas of $77 \%$ for the mixture of slaughterhouse waste and quinoa (RM-QU (25:75)). The increase in inoculum in the mixtures composed of slaughterhouse residues and quinoa increased the biodegradability between 17 and $22 \%$. However, in the mixtures of slaughterhouse waste and amaranth (RM-AM (0:100)), a further increase in inoculum decreased biodegradability by $5 \%$. To predict and simulate methane production, 5 kinetic models were used: modified Gompertz, logistic equation, transfer, cone and Richards. The cone model was the one that best adjusted the experimental values with those predicted with an $\mathrm{R}^{2}$ of 0.982 to 0.999 and RMSE of 0.61 to $6.92 \mathrm{ml} \mathrm{CH}_{4} / \mathrm{g}$ VS. The calculation of the theoretical yield was carried out by stoichiometry and elemental analysis of the samples. Theoretical yields ranged between $480-564 \mathrm{ml} \mathrm{CH}_{4} / \mathrm{g}$ VS for all mixtures of RM with agricultural residues. 
Keywords: methane, co-digestion, slaughterhouse waste, agricultural waste, kinetics, biodegradability.

\section{Introduction}

Efficient management of slaughterhouse waste is one of the most critical problems in developing countries [1]. This means that many wastes not properly treated cause major pollution problems. In the city of Guaranda, Ecuador, the municipal slaughterhouse dumps its waste into the Guaranda River, which causes all agricultural and livestock activities downstream to be significantly affected. In addition, the slaughterhouse does not have a treatment plant to reduce the polluting load of the waste, which means that the discharges have a direct impact on the river. Untreated slaughterhouse waste can create serious problems, due to its high biological oxygen demand (BOD) and chemical oxygen demand (COD) [2]. Hence, there is a prevailing need to reduce the dumping of waste from slaughterhouses and thus avoid contamination from open dumps [3]. On the other hand, the by-products of cattle and pigs that come from the agro-industrial processing of the Guaranda slaughterhouse contain different materials and organic compositions. These materials contain a high energy potential and a high $\mathrm{C} / \mathrm{N}$ ratio due to their high fat and protein content [4]. However, the accumulation of waste from the Guaranda slaughterhouse has been little used as an energy-generating raw material, especially to produce biogas and methane.

Anaerobic co-digestion can be an alternative to treat slaughterhouse waste (RM), through the production of biogas and methane. This technology enables the transformation of RM into energy, constituting an energy-environmental paradigm in waste management. In addition, due to the large amount of residues from agriculture in the region, the digestion process can be optimized through anaerobic co-digestion between the RM and typical agricultural residues of the area: amaranth straw (AM), straw from quinoa (QU) and 
wheat straw (TR). Anaerobic co-digestion notably improves methane production increasing the biodegradability of RM, since they generate synergistic effects in the mixtures reducing the bioresistant, recalcitrant and poorly biodegradable effects [5]. In this sense, the co-digestion of more than one substrate can compensate for the deficiencies of mono-digestion [6]. Mixing different substrates can have a high synergistic effect on methane production as the nutrient content can be balanced. In this way, co-digestion contributes to eliminating the influence of toxic compounds in the digestion process, giving a higher yield of biogas from biomass [7,8].

The Guaranda slaughterhouse produces a large amount of organic waste, such as manure, ruminal content, viscera, hair, blood, hooves, wastewater, among others, which are accumulated or eliminated without any treatment, which increases the generation of bad odors, gases and leachates [9]. . All these residues constitute $25 \%$ of the total weight of the live animal within the slaughterhouses. Cattle produce in the slaughterhouse 7.5 to 30 $\mathrm{kg}$ of manure, mostly semi-liquid, 30 to 35 litres of blood, $66 \mathrm{~kg}$ of bones and 40 to 80 $\mathrm{kg}$ of stomach contents [10]. In addition, as in other slaughterhouses, the Guaranda slaughterhouse generates large volumes of waste with high organic resistance due to the presence of oils, fats and proteins derived from adipose tissue and blood, as well as the energy consumption associated with refrigeration and water heating [11]. More than 3,667 head of cattle are slaughtered annually, generating a large amount of waste that pollutes the environment.

At present there is a diversity of slaughterhouses, which depends on the type, quantity and variety of animals treated. The Guaranda slaughterhouse processes cattle and pigs. Most of the research in the literature addresses the anaerobic digestion of previously pretreated RM, in which the contaminant load has been reduced. This makes the waste generated, as raw material in slaughterhouses, diverse and depends on the type of 
slaughterhouse to be treated. In this sense, this research addresses the anaerobic codigestion of mixed RM not pre-treated with agricultural residues of AM, QU and TR. Furthermore, the effect of inoculum (sewage sludge) on methane yield is evaluated. The research process was carried out under mesophilic conditions and on a laboratory scale.

\section{Materials and methods}

\subsection{Substrates, co-substrates and inoculum used.}

\section{RM and residues of lignocellulosic materials}

Four materials were used for the biochemical methane potential (BMP) experiments: RM was used as the main substrate, the same materials that were collected from the Guaranda municipal slaughterhouse; and straw residues of AM, QU and TR were used as cosubstrates, all residues were collected in the province of Bolívar (Ecuador). Once the samples were collected, they were stored at $4{ }^{\circ} \mathrm{C}$ in polyethylene bags, for conservation purposes. Once the co-substrates were harvested, they were subjected to mechanical pretreatment using a universal cutter mill to reduce the size of the straw. Once the residues were crushed, they were sieved, to obtain a homogeneity of the samples, and at the same time obtain a particle size of less than $3 \mathrm{~mm}$. The inoculum (anaerobic biomass) was obtained from the anaerobic digester of the municipal WWTP of Ibarra (Ecuador).

\section{Characterization of substrates, co-substrates and inoculum.}

The total solids (TS) and the volatile solids (VS) of the waste were measured in triplicate according to the UNE-EN 18134 and UNE-EN ISO 18123 standards. While the TS and VS content of the inoculum was determined in accordance with American Public Health Association methods 2540A-2540G [12]. A portable digital multimeter potentiometer (HACH HQ 40D) was used to determine the $\mathrm{pH}$ of the biodigester samples. Elemental 

analyser.

\subsection{Theoretical methane production}

104

105

$$
\gamma_{\text {teo }}\left(\frac{\mathrm{ml} \mathrm{CH}_{4}}{\mathrm{~g} \mathrm{VS}}\right)=\frac{22400 *(4 \mathrm{a}+\mathrm{b}-2 \mathrm{c}-3 \mathrm{~d}-2 \mathrm{e})}{(12 \mathrm{a}+\mathrm{b}+16 \mathrm{c}+14 \mathrm{~d}+32 \mathrm{e}) * 8}
$$

$$
\begin{aligned}
\mathrm{C}_{\mathrm{a}} \mathrm{H}_{\mathrm{b}} \mathrm{O}_{\mathrm{c}} \mathrm{N}_{\mathrm{d}}+( & \left.\frac{4 \mathrm{a}-\mathrm{b}-2 \mathrm{c}+3 \mathrm{~d}+2 \mathrm{e}}{4}\right) \mathrm{H}_{2} \mathrm{O} \\
& \rightarrow\left(\frac{4 \mathrm{a}+\mathrm{b}-2 \mathrm{c}-3 \mathrm{~d}-2 \mathrm{c}}{8}\right) \mathrm{CH}_{4} \\
& +\left(\frac{4 \mathrm{a}+\mathrm{b}+2 \mathrm{c}+3 \mathrm{~d}+2 \mathrm{e}}{8}\right) \mathrm{CO}_{2}+\mathrm{dNH}_{3}+\mathrm{eH}_{2} \mathrm{~S}
\end{aligned}
$$

111 Furthermore, starting from the theoretical chemical oxygen demand (CODt), the methane 112 production $\left(\gamma_{\mathrm{CODt}}\right)$ can be determined using Equation 3 [17,18].

$$
\gamma_{\text {CODt }}\left(\frac{\mathrm{ml} \mathrm{CH}_{4}}{\mathrm{~g} \mathrm{VS}}\right)=\frac{\mathrm{n}_{\mathrm{CH} 4} \cdot \mathrm{RT}}{\text { P.VS }}
$$

113 where $\gamma_{\mathrm{CODt}}$ is the theoretical production, $\mathrm{R}$ is the gas constant $(\mathrm{R}=0.082 \mathrm{~atm} 1 / \mathrm{mol} \mathrm{K})$, $114 \mathrm{~T}$ is the biodigester temperature $(298 \mathrm{~K}), \mathrm{P}$ is the atmospheric pressure (1atm), VS added 115 (g) are the volatile solids of the substrate and $\mathrm{n}_{\mathrm{CH} 4}$ is the amount of molecular methane (mol). 
117 The value of $\mathrm{n}_{\mathrm{CH} 4}$ has been determined from Equation 4 [19].

$$
\mathrm{n}_{\mathrm{CH} 4}=\frac{\mathrm{CODt}}{64\left(\frac{\mathrm{g}}{\mathrm{mol}}\right)}
$$

118 The CODt of all substrates and co-substrates was estimated through their elemental 119 composition and the stoichiometry of the oxidation reaction (Eq. 5), using equation (Eq.

120 6) $[15]$.

$$
\begin{aligned}
\mathrm{C}_{\mathrm{a}} \mathrm{H}_{\mathrm{b}} \mathrm{O}_{\mathrm{c}} \mathrm{N}_{\mathrm{d}}+ & \left(\frac{4 \mathrm{a}+\mathrm{b}-2 \mathrm{c}-3 \mathrm{~d}+2 \mathrm{e}}{4}\right) \mathrm{O}_{2} \\
& \rightarrow \mathrm{aCO}_{2}\left(\frac{\mathrm{b}-3 \mathrm{~d}}{2}\right) \mathrm{CH}_{4}+\mathrm{eH}_{2} \mathrm{O}+\mathrm{dNH}_{3}
\end{aligned}
$$

$$
\operatorname{CODt}\left(\frac{\mathrm{ml} \mathrm{O}_{4}}{\mathrm{~g} \mathrm{VS}}\right)=\frac{\left(2 \mathrm{a}+\frac{\mathrm{b}}{2}-\mathrm{c}-\frac{3 \mathrm{~d}}{2}\right) * 16}{(12 \mathrm{a}+\mathrm{b}+16 \mathrm{c}+14 \mathrm{~d})} * 1000
$$

122

\subsection{Biodegradability of anaerobic co-digestion}

124

The biodegradability was calculated from the experimental methane yield $\left(\gamma_{\exp }\right)$ and the theoretical methane yields ( $\gamma$ teo and $\left.\gamma_{\mathrm{COD}}\right)$, the anaerobic biodegradability $(\varepsilon)$ of the substrate could be calculated according to the equation. Equation 7 which estimates the

127 calculation of biodegradability [20,21].

$$
\varepsilon=\frac{\gamma_{(\exp )}}{\gamma_{(\text {teo })}} \cdot 100 \%
$$

128 To determine the influence of the substrate and the co-substrates on the biodegradability 129 of the biodigesters, their synergistic and antagonistic effects were estimated. The 130 parameter $\alpha$ allows evaluating the effect of the co-substrate and co-substrates in the 
131 mixtures to be co-digest. $\alpha$ was determined according to the experimental yield and the weighted methane yield (Equation 8) [17].

$$
\alpha=\frac{\gamma_{\exp }}{\gamma_{\text {pond }}}
$$

Eq. 8

133 Where $\gamma_{\exp }$ refers to the experimental performance obtained by the BMP and $\gamma_{\text {pond }}$ 134 corresponds to the weighted experimental performance.

$\gamma_{\text {pon }}$ is determined by Equation 9 [22].

$$
\gamma_{\text {pond }}=\frac{\gamma_{\mathrm{sp}} \cdot \lambda+\gamma_{\mathrm{cs} \cdot} \beta}{\lambda+\beta}
$$

136 Where, $\gamma_{\mathrm{sp}}$ refers to the methane production obtained from the digestion of the main 137 substrate calculated as monosubstrate. On the other hand, $\gamma_{\mathrm{cs}}$ is the production obtained through the singular digestion of the different co-substrates. The values of $\lambda$ and $\beta$ correspond to the VS fractions of the main substrates and the co-substrates.

\subsection{Experimental setup and procedure}

\section{Initial conditions of co-digestion}

Nine co-digestion conditions between the RM manure substrate and the AM, QU and TR co-substrates were tested, using different substrate:co-substrate ratios. For both the RM:AM, RM:QU and RM:TR ratios, three volatile solids proportionality ratios were used: $25: 75,50: 50$ and 75:25. Two substrate/inoculum ratios (SIR) were performed for all experiments: SIR 1:1 (g: g VS) and SIR 1:2 (g: g VS). The C/N ratio was determined based on elemental analysis and varied depending on the amount of VS mixture between the substrate and co-substrate (Table 1). 
152

153

154

BMP experiments were used to determine the influence of co-substrates and inoculum on methane yield during anaerobic co-digestion of RM. All BMP experiments were performed in triplicate, in $311 \mathrm{ml}$ glass biodigesters filled with $60 \%$ working volume. The proportions of the substrates and co-substrates before being put into the biodigester were mixed with a kitchen blender to ensure that the experimental samples are uniform. Once the co-digestion mixtures had been made, the batch biodigesters were closed with rubber septa and aluminium lids to guarantee anaerobic conditions inside. The experiments were carried out for 40 days and $37^{\circ} \mathrm{C}$. Distilled water was added to obtain a final working volume of $60 \%$ of the volume of the biodigesters when necessary. As controls, three blank biodigesters containing only inoculum and distilled water were also incubated under the same conditions as the rest of the biodigesters. The biogas yield from these blank biodigesters was used to correct for the biogas produced solely by the inoculum.

The volume of biogas produced in each biodigester was calculated daily by measuring the pressure in the headspace of each biodigester using a portable pressure gauge (Delta OHM HD 2124.2) (Figure 1). The pressure in the head space of the biodigester was measured after the insertion of a syringe needle through the rubber stopper. The composition of the biogas (content of $\mathrm{CH}_{4}, \mathrm{O}_{2}, \mathrm{CO}_{2}, \mathrm{H}_{2} \mathrm{~S}$ ) was measured using the BIOGAS GA-5000 meter from Geotech. In this way, using a $200 \mathrm{ml}$ hermetic syringe, biogas samples were taken from the headspace of each biodigester after releasing the gas. Before measuring the biogas composition in the headspace, the reactors were shaken for two minutes at $100 \mathrm{rev} / \mathrm{min}$. The composition of the biogas was measured once a day until the end of the fermentation. 
174 The maximum methane yield was expressed as the maximum volumetric yield of methane 175 per gram of initial substrate VS added $\left(\mathrm{ml} \mathrm{CH}_{4} / \mathrm{g}\right.$ VS). Each trial was performed in 176 triplicate, and the results were obtained as the average of these.

\section{$177 \quad 2.5$ Experimental modelling of the data to estimate the BMP.}

178 Five kinetic models were selected, that is, the modified Gompertz kinetic model

179 (Equation (10)), the transfer model (Equation (11)), the logistic function model (Equation (12)), the cone model (Equation (13)), and the modified Richards model (Equation (14)) to fit the cumulative methane production obtained from the experimental data.

The most suitable kinetic model was selected not only to predict the efficiency of the biodigesters used, but also to correctly analyse the metabolic pathways and the mechanisms involved during $\mathrm{AD}$ of the co-digestion of slaughterhouse waste with lignocellulosic waste [23]. However, all five kinetic models have individual specific benefits. The cone model is the simplest model and provides information on the degradation of substrates during the hydrolysis phase through the hydrolysis rate coefficient $\left(\mathrm{k} ; \mathrm{d}^{-1}\right)$ [24]. The modified Gompertz, logistic, transfer and Richards model are more sophisticated, since they take into account the phenomenon of the latency phase $\left(\mathrm{t}_{\text {lag }} ; \mathrm{d}\right)$ and the maximum specific methane production rate $\left(v_{\max }\right)$ [25]. Therefore, the five kinetic models were used in this study to determine the cumulative biogas production potential, the hydrolysis kinetics, the lag phase duration, and the maximum methane production. All the parameters of the kinetic models were determined by fitting between the experimental and estimated data through the statistical tool STATISTISCA 10. To evaluate the performance of the models, the coefficient of determination $\left(\mathrm{R}^{2}\right)$ and the percentage of squared error were used. medium (RMSE; \%). These coefficients were calculated to provide additional information on the goodness of fit of the different models. 
199 If the model accurately predicts the kinetic coefficient, $\mathrm{R}^{2}$ should be close to 1 and the 200 RMSE should be as close to 0.

201

Modified Gompertz model [26]:

$$
M=M_{\mathrm{e}} \cdot \exp \left\{-\exp \left[\frac{v_{\max } * e}{M_{\mathrm{e}}}\left(t_{\text {lag }}-\mathrm{t}\right)+1\right]\right\}
$$

Eq. 10

202

203

Transfer model [27]:

$$
M=M_{\mathrm{e}}\left\{1-\exp \left[-\frac{v_{\mathrm{max}}}{M_{\mathrm{e}}}\left(t-\mathrm{t}_{\mathrm{lag}}\right)\right]\right\}
$$

204

205

Logistics function model [27]:

$$
M=\frac{M_{\mathrm{e}}}{1+\exp \left[\frac{4 v_{\max }\left(t_{\text {lag }}-t\right)}{M_{\mathrm{e}}}+2\right]}
$$

206

207 Cone model [28]:

208

$$
M=\frac{M_{e}}{1+(k \cdot t)^{-n}}
$$

209

Modified Richard model [28]:

$$
M=\frac{M_{e}}{1+(k \cdot t)^{-n}}
$$

Eq. 14

210

211 Where,

$212 M$ is the amount of methane $\left(\mathrm{ml} / \mathrm{g} \mathrm{VS}_{\text {added }}\right)$ with respect to time $\mathrm{t}$ (days),

$213 M_{e}$ is the maximum methane potential of the substrate ( $\mathrm{ml} / \mathrm{g} \mathrm{VS}$ added),

$214 k$ is the hydrolysis rate constant $\left(\mathrm{d}^{-1}\right)$,

$215 t$ is the digestion time (days),

$216 v_{\max }$ is the maximum biogas production rate $(\mathrm{ml} / \mathrm{g} \mathrm{VS}$ added. $\mathrm{d})$,

$217 \quad t_{\text {lag }}$ is the time of the lag phase (days),

$218 \quad e$ is the Euler function equal to 2.7183. 


\subsection{Characteristics of the raw material}

221

222

223

224

Table 2 shows the characterization of the RM manure, used as the main substrate, and the three lignocellulosic biomasses used as co-substrates. Through this characterization, the great difference between the selected biomasses stands out, mainly due to the different percentages of its components: TS, VS, VS/TS and their $\mathrm{C} / \mathrm{N}$ ratio. When analysing the MR substrate, it was obtained that the values of TS, VS and VS/TS were $9.6 \%, 6.8 \%$ and 0.70, respectively. However, the RM results were lower than those obtained by Álvarez and Liden [29], who obtained TS of $18.8 \%$, VS of $20 \%$ and an VS/TS ratio of 0.94.

On the other hand, the three co-substrates analysed (AM, QU and TR), presented a high content of TS, that is, $88.2 ; 87.0$ and $92.6 \%$ respectively. In the same way, they had a high content of VS, that is, $65.9 ; 50.8$ and $71.5 \%$ respectively, compared to the RM.

The TR residues were characterized by having the highest values of TS (92.6\%), VS (71.5\%) and VS/TS (0.77). However, these results were lower than those obtained by Sun et al. [30], who obtained values of TS, VS and VS/TS of $74.1 \% ; 62.9 \%$ and 0.84 , respectively. For its part, the AM co-substrate presented similar characteristics of VS (88.2\%), TS (65.9\%) and VS/TS (0.75) to those of TR. Furthermore, the AM results were superior to those obtained by Seppälä et al. [31], who reported TS and VS values of $18.0 \%$ and $14.4 \%$ respectively; however, they obtained a higher VS/TS ratio (0.80). Finally, the QU co-substrate presented a high value of TS (87.0\%) and low values of VS $(50.8 \%)$ and VS/TS (0.58). Thus, the results of TS, VS and VS/TS of QU, were lower than those obtained by Alvarez \& Lidén [29], who obtained values of 95.3\%; 91.9\% and 0.88, respectively. On the other hand, the results of TS, VS and VS/TS of QU, were superior to those of Pabón [32], who obtained data of TS and VS of $22 \%$ and 19\% respectively; however, he obtained a higher VS/TS ratio (0.86). 
The RM and TR residues were characterized by presenting the highest $\mathrm{C} / \mathrm{N}$ contents, 101.9 and 29.6 respectively, while the QU $(12,9)$ and AM residues showed a lower and similar $\mathrm{C} / \mathrm{N}$ ratio. Thus, the high $\mathrm{C} / \mathrm{N}$ ratio of the $\mathrm{RM}$ and $\mathrm{TR}$ residues could compensate for the low $\mathrm{C} / \mathrm{N}$ ratios of the $\mathrm{QU}$ and $\mathrm{AM}$ residues through the co-digestion process. The mixture of different residues allows an optimal digestion process between the different substrates and co-substrates tested. On the other hand, having a fairly high $\mathrm{C} / \mathrm{N}$ value as is the case of RM $(101,9)$ does not significantly affect the efficiency of digestion [33], since not all the carbon and nitrogen in the matter raw are available for anaerobic digestion [29]. In this sense, the biodegradable $\mathrm{C} / \mathrm{N}$ ratios are lower than the total $\mathrm{C} / \mathrm{N}$ ratios of the substrates and co-substrates [34].

Even though the inoculum (IN) presented a low solids content (3.9\% and $2.3 \%$ in TS and VS, respectively). The IN values were like those presented by Sun et al. [30], who reported TS, VS and VS/TS of 5.9\%; 3.19\% and 0.58. Similarly, IN results were comparable to those of Pellera \& Gidarakos [15], who reported TS, VS and VS/TS of $2.7 \% ; 1.7 \%$ and 0.62 , respectively.

\subsection{Potential methane production}

\section{Daily and cumulative methane production}

261

262

263

264

The daily and cumulative production of biogas from slaughterhouse waste with amaranth, quinoa and wheat straw waste are shown in Figure 2. It is observed that the evolution of methane production from slaughterhouse waste is influenced by two factors: the influence of the substrate and inoculum ratio, and the influence of agricultural residues (AM, QU and TR).

Increasing the amount of inoculum from a SIR1:1 to a SIR1:2 increased the daily methane yield in most biodigesters during the first days of anaerobic digestion (AD). For a SIR1:1, 
the amount of methane, during the first 10 days, was between $46.80 \%$ and $68.70 \%$ of the total amount of accumulated methane. In contrast, when the inoculum was increased to a SIR1:2, the methane production increased slightly in a range of $46.17-74.58 \%$ on day 10 . According to Fernández et al. [35], an increase in inoculum can increase the degradation capacity of microbial populations on the organic load, thus avoiding the accumulation of volatile fatty acids (VFA) and the inhibition of methanogenesis; causing methane production to increase. Furthermore, the behaviour of daily production was determined by the type of co-substrate used. The highest peaks of daily methane production were obtained in the mixtures of slaughterhouse waste with quinoa straw. Thus, during day 2 , the RM-AM (25:75), RM-QU (50:50) mixtures experienced the highest methane peaks (34.46 $\mathrm{ml} \mathrm{CH}_{4} / \mathrm{g} \mathrm{VS}$ and $41.11 \mathrm{ml} \mathrm{CH}_{4} / \mathrm{g}$ VS) for a SIR1:1 and a SIR1:2, respectively.

The highest cumulative methane yields were found in trials using a SIR1:2, especially in the RM and QU mixtures. Thus, the mixtures RM-QU (25:75) and RM-QU (25:75) generated results of 406.86 and $391.45 \mathrm{ml} \mathrm{CH}_{4} / \mathrm{g}$ VS, respectively. Similarly, the RMAM mixture (25:75) generated high amounts of methane (379.38 $\left.\mathrm{ml} \mathrm{CH}_{4} / \mathrm{g} \mathrm{VS}\right)$. The percentages of improvement in methane production, when increasing the inoculum from a SIR1:1 to a SIR1:2, were 0.6-23\%; however, the individual substrate of RM decreased by $5 \%$ with increasing inoculum. Co-digestion also enhanced methane production from individual RM substrates. For a SIR1:1 co-digestion increased methane production by 1$14 \%$; and for a SIR1:2 production increased by $0.5-22 \%$.

The results obtained in this study are similar to those of other authors in the literature [3639], who carried out the co-digestion of RM with various crops (straw and fruit and vegetable waste) and obtained methane productions from 461, 499, 208 and $380 \mathrm{ml} \mathrm{CH}_{4} / \mathrm{g}$ 
by Cuentos et al. [40], who obtained yields of $400 \mathrm{ml} \mathrm{CH}_{4} / \mathrm{g} \mathrm{VS}$ when they co-digested liquid waste from poultry slaughterhouses and solid urban waste. Furthermore, the RM results obtained are much higher than those obtained by Álvarez y Lidén [29], who reported that the co-digestion of pig slaughterhouse waste with pig manure produces specific methane yields of $260 \mathrm{ml} \mathrm{CH}_{4} / \mathrm{g}$ VS. The results obtained were also greater than the results reported by Rosenwinkel and Meyer [41], who obtained $230 \mathrm{ml} \mathrm{CH} 4 / \mathrm{g} \mathrm{VS}$ when they co-digested slaughterhouse waste (stomach content of pigs and cows) with sewage sludge. However, the results were somewhat lower than those reported by Luste and Luostarinen [4], who obtained results of $430 \mathrm{ml} \mathrm{CH}_{4} / \mathrm{g}$ VS when they worked on the co-digestion of livestock waste (pig slaughterhouse) with sewage sludge.

\section{Synergistic effects of agricultural co-substrates.}

Agricultural residues from AM, QU and TR had a significant influence on methane production. The synergistic effects of agricultural residues are reflected in the improvement of the methane yield of the individual mixtures of the RM. It was shown that mixtures with a higher amount of agricultural residues increase methane yield regardless of the type of SIR used. However, the highest productions were obtained when 25\% RM and 75\% AM, QU and TR residues were used. Thus, for the SIR1:1 the mixtures RM-AM (25:75), RM-QU (25:75) and RM-TR (25:75) generated 363.17; 335.94 and 301.61 $\mathrm{CH}_{4} / \mathrm{g}$ VS, respectively. Similarly, for a SIR1:2 the mixtures RM-AM (25:75), RM-QU (25:75) and RM-TR (25:75) generated 379.78; 406.86 and $303.71 \mathrm{CH}_{4} / \mathrm{g}$ VS, respectively (Figure 3).

The average methane content of the biogas produced in all the reactors varied between $54.31 \%$ and $68.74 \%$ for the SIR $1: 1$ and between $54.42 \%$ and $76.55 \%$ for the SIR $1: 2$. However, the increase in inoculum increased methane production in most of the 

mixtures in which decreased by $1.4 ; 0.46$ and $0.54 \%$. The percentages of methane obtained in this study were very similar to those reported by other authors in the literature. Thus, for example, Borowski [42] found methane content in biogas between 55\% and $60 \%$ for the monodigestion of municipal solid waste and between $58 \%$ and $66 \%$ for the co-digestion of municipal solid waste and sewage sludge. Regarding fruit and vegetable residues, Bouallagui et al. [43] reported a methane content in biogas of $64 \%$, while Scano et al. [44] reported average methane content of 75\%. Lin et al. [45] reported percentages of methane between $53.7 \%$ and $63.8 \%$ on the co-digestion of fruit and vegetable residues, and food waste.

In addition, Figure 3 shows the biodegradability ( $\varepsilon_{\text {teo }}$ and $\left.\varepsilon_{\mathrm{COD}}\right)$ for all the mixtures used. The results ranged from 46-73\% for the SIR1:1 and between 56 and 77\% for the SIR1:2. Thus, an increase in the amount of inoculum increased the biodegradability in a range of $0.20-18 \%$. The data showed considerable concordance between $\varepsilon_{\text {teo }}$ and $\varepsilon_{\mathrm{COD}}$, showing that the theoretical methane production values obtained by Buswell's stoichiometric method $\left(\gamma \mathrm{t}_{\mathrm{eo}}\right)$ and elemental analysis of CODt $\left(\varepsilon_{\mathrm{COD}}\right)$ were similar (Figure 4).

Biodegradability values were correlated with experimental methane production. This agreement resulted in a coefficient of determination greater than $95 \%$ being obtained for both the SIR1:1 and the SIR1:2.

\subsection{Kinetic study of the anaerobic digestion of slaughterhouse waste}

The modified Gompertz, transfer, logistic equation, cone and Richards models were evaluated in all biodigesters in the SIR 1:1 and SIR 1:2 assays. The kinetic parameters (maximum specific methane production rate $\left(v_{\max }\right)$, rate constant $(\mathrm{k})$, lag phase time $\left(\mathrm{tl}_{\mathrm{ag}}\right)$ and specific maximum methane production $\left(\mathrm{M}_{\mathrm{e}}\right)$ ), as well as the statistical parameters 
340 (coefficient of determination $\left(\mathrm{R}^{2}\right)$ and mean square error (RMSE)) are shown in Table 3 and Table 4.

\section{Maximum specified rate of methane production}

343 The vmax values were maximum in the SIR 1:2, specifically in the mixtures RM-AM (0:100) both for the Gompertz model (21.19 $\mathrm{ml} \mathrm{CH}_{4} / \mathrm{g}$ VS d), logistic equation $(31.34 \mathrm{ml}$ $\mathrm{CH}_{4} / \mathrm{g} \mathrm{VS} \mathrm{d}$ ) and blot pattern (41.23 $\mathrm{ml} \mathrm{CH}_{4} / \mathrm{g}$ VS d). While Richard's model had maximums of 43.75 and $33.05 \mathrm{ml} \mathrm{CH}_{4} / \mathrm{g}$ VS $\mathrm{d}$ in the RM-QU (25:75) and RM-AM (25:75) mixtures, respectively. In general, the results showed that $v_{\max }$ is more homogeneous in the modified Gompertz sigmoidal models and in the logistic equation. However, in the Richards model, vmax was not highly correlated with the transfer model and the two previous sigmoidal models. This is because the Richards equation is generally flawed due to its inconsistent properties [46]. This means that the behaviour of the Richards equation is exponential in small ranges or low densities. In this way, the parameters of different curves fitted using the Richards growth model are not necessarily equivalent.

\section{Specific Maximum Methane Production}

The results of the asymptote $\mathrm{M}_{\mathrm{e}}$ of the sigmoidal models were not like each other. The fact that $M_{e}$ is not fully correlated with all kinetic models is because $M_{e}$ differed from experimentally obtained methane production. The predicted and observed values of the sigmoidal models registered differences of $0.25-19.48 \%$ (modified Gompertz), 0.32 $18.22 \%$ (logistic equation), $0.85 \%$ and $12.69 \%$ (model of transfer), cone model (20.06$36.97 \%$ ) and $0.40-19.42 \%$ (Richards). However, the mean differences obtained between the experimental performance and $\mathrm{M}_{\mathrm{e}}$ were like those obtained by Ware and Power [47], who obtained differences for poultry slaughterhouse residues of 0.54 and $27.07 \%$. On the 
other hand, the differences between the experimental performance and $\mathrm{M}_{\mathrm{e}}$ of this study were higher than those of Patil et al. [48] who obtained $8.7 \%$ results when predicting the water hyacinth yield. Similarly, the results of this study were superior to the results of Raposo et al. [49] who reported differences of $10 \%$ when predicting the yield of the sunflower oil cake when using first-order kinetic models.

\section{Delay phase time}

Regarding the latency period $\left(\mathrm{t}_{\mathrm{lag}}\right)$, the RM co-digestion recorded null latency periods for all models, except for the transfer model, which presented delay phases of 1.16 and $0.77 \mathrm{~d}$ for the trials RM-AM (0:100) and RM-TR (25:75), respectively. The fact that there are zero latency phases means that the biodegradability of the raw materials is very high and there is little presence of inhibitors [50]. Furthermore, according to Kafle et al. [51] the low duration of the lag phase in the digestion processes can be attributed to a low content of proteins and fats in the substrates.

\section{First order constant}

The hydrolysis constant $(\mathrm{k})$ was much higher as the amount of inoculum in the mixtures increased. Thus, in the SIR1:1, $\mathrm{k}$ varied between $0.05-0.14 \mathrm{~d}^{-1}$, while in the SIR1:2, $\mathrm{k}$ varied between $0.06-0.18 \mathrm{~d}^{-1}$. Furthermore, the constant $\mathrm{k}$ increased for biodigesters composed of RM-QU and decreased for biodigesters composed of RM-TR. The results of this study were inferior to other studies in the literature. So, for example, Song and Clarke. [52] found $\mathrm{k}$ of $0.45 \mathrm{~d}^{-1}$ for cellulose in a mixed culture enriched with landfill waste. $\mathrm{Hu}$ and $\mathrm{Yu}$ [53] used ruminal microorganisms to improve the anaerobic digestion of the corn cob and estimated that $\mathrm{k}$ was $0.94 \mathrm{~d}^{-1}$. On the other hand, in studies on the codigestion of microalgae biomass with sludge, values of $\mathrm{k}$ between $0.25-0.28 \mathrm{~d}^{-1}$ have been 
obtained [54]. Similarly, in microalgae mono-digestion tests, $\mathrm{k}$ values of $0.07 \mathrm{~d}^{-1}$ have been obtained [55].

\section{Discussion}

In this research, the daily methane production remained constant during the first three days, subsequently it decreased continuously and remained at very low levels. The early onset of microbial activity caused the mixtures to generate more than $70 \%$ methane during the first 10 days. According to Zhang et al. [56] consider that around $80 \%$ of the methane can be obtained during the first ten days of digestion. Furthermore, many authors in the literature suggest that some of the BMP trials require short treatment periods [57]. A possible reason why a high generation of methane has been obtained during the first days is because the inoculum and the methanogenic microorganisms immediately acclimatized to the mixtures used in the tests $[58,59]$. The methane accumulation curves also reflected a rapid adaptation of the microorganisms, since it caused very small and even zero lag periods (tlag) to be shown. In general, the accumulation curves showed a rapid exponential growth during the start of digestion. According to Remigi \& Buckley [60], the rapid growth of the methane accumulation curves is due to three factors: use of easily biodegradable materials, immediate production of methane when starting the AD process, and the presence of a stationary phase as the biodegradable material is depleted.

The use of straw residues from amaranth, quinoa and wheat increased methane production from slaughterhouse residues. According to Vivekanand et al. [61] a mixture has a synergistic effect if more methane is produced relative to an estimate based on methane yields from single substrate digestions. In this case, the simultaneous presence of RMs with various co-substrates (AM, QU and TR) improved the co-digestion process, due to the synergistic interactions of the mixtures [62]. In this way, a mixture of different substrate fractions with different characteristics can provide all the nutrients and trace 
412 elements that microorganisms need [37] This fact is justified, since the catalytic centers

413 of the enzymes involved in the methanogenic pathways depend to a great extent on the 414 micronutrients [63]. In addition, the synergistic effects of mixtures can contribute trace elements, nutrients, enzymes, or any other amendment that a substrate alone may lack [64]. In short, the mixture of many heterogeneous substrates increases the activity of microorganisms and, therefore, stimulates AD. In this study, the most relevant findings were the following: a higher concentration of SV of the co-substrates (AM, QU and TR) in the mixtures caused the production of methane to increase up to $22 \%$ in the individual mixtures of the RM; in addition, the co-digestion of the RM-QU and RM-AM mixtures generated the highest methane productions regardless of their SIR, and finally, the concentrations of 50-75\% of AM and QU were optimal to improve methane production. In the characterization of the raw materials, the VS of the slaughterhouse RM were 6.8 while the VS of the straw waste of AM, QU and TR were higher with $66 \%, 51 \%$ and $72 \%$ respectively. In this case, the use of agricultural residues helped to balance the physicochemical properties of the RM by improving the biodegradability of the VS of the mixtures [65-67]. In this way, the addition of agricultural residues provided a better substrate for methanogenic bacteria, causing them to accelerate the fermentation process and increase methane production $[68,69]$

For a SIR1:2, the co-digestion of the RM-QU and RM-AM mixtures generated the highest amount of methane with ranges of 378-407 and 320-380 ml/g VS, respectively. However, the RM-QU (25:75) mixtures generated 7\% more than the RM-AM (25:75) mixtures. Similarly, the RM-QU (50:50) mixtures generated 13\% more than the RM-AM (50:50) mixtures. These results were very similar to other studies in the scientific literature. Thus, in the co-digestion of urban solid waste, Mojapelo et al. [70] and Kubaska et al. [71] reported $386 \mathrm{ml} / \mathrm{g}$ VS and $385 \mathrm{ml} / \mathrm{g}$ VS, respectively. Salminen et al. [72], by fermenting 
437 solid waste from poultry slaughterhouses, they obtained 550 to $670 \mathrm{ml} / \mathrm{g} \mathrm{VS}$. Li, et al. 438 [73], presented yields of $300 \mathrm{ml} / \mathrm{g} \mathrm{VS}$ for the AD of lignocellulosic biomass of agricultural 439 residues. Similarly, Mussgnug et al. [74], reported methane productions for the anaerobic digestion of 6 different microalgae between 218 and $387 \mathrm{ml} / \mathrm{g}$ VS. Although the reported results were comparable with other previous studies, the methane yields were of medium 442 production. According to Velázquez et al. [75] digestion processes can be classified into three groups according to methane production potential: low production processes (150 and $300 \mathrm{ml} / \mathrm{g} \mathrm{VS}$ ), medium production processes (300 and $450 \mathrm{ml} / \mathrm{g}$ VS) and processes high production (more than $450 \mathrm{ml} / \mathrm{g} \mathrm{VS}$ ).

446 According to Raposo et al. [76] the experimental methane yield can be used to calculate the level of anaerobic biodegradability under the defined test conditions compared to its theoretical value. In this study, theoretical calculations provided a rough first estimate of methane production. However, it was found that the theoretical yield was much higher than the experimental one. According to Herrmann \& Rath [77], the theoretical estimates are usually much higher than the experimental yield because in the theoretical analysis all biomass is biodegradable. On the other hand, in obtaining experimental methane, the suitability of fermentation decreases with the lignification of the substrate, since lignin is not degraded in the fermenter and makes the degradation of other components of the cell wall difficult [78]. Furthermore, in experimental trials there is a wide variety of substances that can inhibit anaerobic processes [79]. In short, the conversion of organic substances into methane, in the experimental tests, is lower than in the theoretical estimates since the ideal conditions cannot be met [80]. The tests of this research showed that the data for obtaining biodegradability are adequate, since the results of 460 biodegradability and experimental performance showed a concordance of more than $95 \%$ 461 in their coefficient of determination $\left(R^{2}\right)$ (Figure 4). This concordance between 
biodegradability and experimental performance was superior to the tests performed by

463 Labatut et al. [64] on digestion of complex substrates.

464 For the RM methane production kinetics, several kinetic models were used: modified 465 Gompertz model, logistic equation, modified Richards model, transfer model and cone 466 model. Models widely used in anaerobic digestion to produce methane [81,49]. It is worth noting that the convenience and precision of the models always depends on the experimental conditions, the operating parameters, as well as the origin of the inoculum and the type of substrates used [82]. In this study, all the models experienced an $\mathrm{R}^{2}$ above 0.95 (Tables 3 and 4), however, none of them provided a precise fit to the experimental data. In general, all models consist of monotonically increasing functions that always increase and are never equal to zero or decrease [83]. Furthermore, all equations have a single point of inflection, where the curvature changes from concave to convex or vice versa [84]. This has meant that the models do not fully describe the kinetic behaviour of the tests.

The kinetic model with the highest $\mathrm{R}^{2}$ (0.982-0.999) and the lowest RMSE (0.61-6.92) ml $\left.\mathrm{CH}_{4} / \mathrm{g} \mathrm{VS}\right)$ was the cone model. Similarly, the blot model fitted the data with an $\mathrm{R}^{2}(0.990-$ 0.999) and an RMSE of (1.54-8.78 $\left.\mathrm{ml} \mathrm{CH}_{4} / \mathrm{g} \mathrm{VS}\right)$. While the model of the logistic equation is the one that best adjusted the values observed with the models, since the value of $\mathrm{R}^{2}$ and the RMSE ranged between (0.957-0.996) and (7.43-13.35 $\mathrm{ml} \mathrm{CH}_{4} / \mathrm{g} \mathrm{VS}$ ) respectively. On the other hand, the modified Gompertz and Richards models had a lot of similarity to each other. In the modified Gompertz model, the correlation coefficient presented an $\mathrm{R}^{2}$ of 0.977 to 0.999 and an RMSE of 4.09 to $11.39 \mathrm{ml} \mathrm{CH}_{4} / \mathrm{g} \mathrm{VS}$ ); while in the Richards model it presented an $\mathrm{R}^{2}$ of 0.978 to 0.999 and RMSE between 4.11 and $11.40 \mathrm{ml} \mathrm{CH}_{4} / \mathrm{g}$ VS. The similarity between the Richards model and the modified 
very small (0.001-0.022). In this sense, the smaller the parameter " $\mathrm{d}$ ", the more similarity there is between the two models [81]. The Richards model gives some flexibility to the curve, allowing it to be adjustable in the event of partial inhibition of the digestion process [47]. Based on the R2 and RMSE values, the Cone model was the best model to adjust the measured and predicted methane yields. Similarly, in other digestion studies, they considered that the cone and first-order models are the most recommended and that best adjust methane yields $[85,86]$.

\section{Conclusions}

BMP was investigated using RM as the main substrate in co-digestion with agricultural crop residues (co-substrates). It was determined that the proportions of the mixtures between the substrate and the co-substrates play a key role in the rate of degradation of organic matter. Furthermore, it is concluded that SIR has a significant influence on methane production and biodegradability of the raw materials used. Increasing inoculum from $50 \%$ to $66.33 \%$ caused all mixes to increase methane production by up to $22 \%$. Concentrations of 50-75\% of AM and QU were optimal to improve methane production with ranges of 320-407 ml/g VS. It was shown that the higher the concentration of the cosubstrate, the higher the methane production. The RM kinetic study revealed that the lag phase was zero in all tests for the Gompertz, Richards and logistic equation sigmoidal models. While the transfer model experiment resulted in latency phases of 1.16 days. The differences in methane production between the predicted and observed values of the sigmoidal models were $0.25-19.48 \%$ (modified Gompertz), 0.32-18.22\% (logistic equation) and $0.40-19.42 \%$ (Richards). For its part, the cone model experienced differences between 20 and $36 \%$ and the transfer model experienced a difference between $0.85 \%$ and $12.69 \%$. The model that best adjusted the observed and predicted values was the cone model with an $\mathrm{R}^{2}$ of 0.982 to 0.999 and $\mathrm{RMSE}$ of 0.61 to $6.92 \mathrm{CH}_{4} / \mathrm{g}$ VS. 
512 Author Contributions: "Conceptualization, B. Velázquez-Martí and O.W. Meneses-

513 Quelal; methodology, B. Velázquez-Martí, O.W. Meneses-Quelal, Z. Niño-Ruiz;

514 validation, B. Velázquez-Martí, Z. Niño-Ruiz; formal analysis, B. Velázquez-Martí,

515 O.W. Meneses-Quelal, J. Gaibor-Chávez; investigation, writing-original draft

516 preparation, B. Velázquez-Martí, O.W. Meneses-Quelal; writing—review and editing, B.

517 Velázquez-Martí, Z. Niño-Ruiz; funding acquisition, B. Velázquez-Martí, Z. Niño-Ruiz,

518 J. Gaibor-Chávez.

519 Acknowledgments: This work has been carried out within the framework of the project

520 "Analysis of the implementation of biomass exploitation chains in rural communities in

521 the province of Bolívar (Ecuador)" of the ADSIEO-COOPERATION program of the

522 Polytechnic University of Valencia (UPV). The Ecuadorian Energy Exploitation

523 Research Network of Biomass (ECUMASA) and the IBEROMASA Network of the

524 Ibero-American Program of Science and Technology for Development (CYTED) have

525 participated in this program.

526 Conflicts of Interest: "The authors declare no conflict of interest." 


\section{REFERENCIAS}

528

529

530

531

532

533

534

535

536

537

538

539

540

541

542

543

544

545

546

547

548

549

550

551

552

553

554

555

556

557

558

559

560

561

562

1. Guerrero J, Ramirez I (2004) Manejo ambiental de residuos en mataderos de pequeños municipios. Sci Tech 10:199-204

2. Edelmann W, Schleiss K, Joss A (2000) Ecological, energetic and economic comparison of anaerobic digestion with different competing technologies to treat biogenic wastes. Water Sci Technol 41:263-273.

https://doi.org/10.2166/wst.2000.0080

3. Galgani P, van der Voet E, Korevaar G (2014) Composting, anaerobic digestion and biochar production in Ghana. Environmental-economic assessment in the context of voluntary carbon markets. Waste Manag 34:2454-2465. https://doi.org/https://doi.org/10.1016/j.wasman.2014.07.027

4. Luste S, Luostarinen S (2010) Anaerobic co-digestion of meat-processing byproducts and sewage sludge - Effect of hygienization and organic loading rate. Bioresour Technol 101:2657-2664. https://doi.org/https://doi.org/10.1016/j.biortech.2009.10.071

5. Bustillo-Lecompte C (2017) Slaughterhouse Wastewater: Treatment, Management and Resource Recovery. In: Ahmad MME-RFE-Z (ed). IntechOpen, Rijeka, p Ch. 8

6. Li R, Chen S, Li X, et al (2009) Anaerobic Codigestion of Kitchen Waste with Cattle Manure for Biogas Production. Energy \& Fuels 23:2225-2228. https://doi.org/10.1021/ef8008772

7. Alvarez R, Lidén G (2008) Semi-continuous co-digestion of solid slaughterhouse waste, manure, and fruit and vegetable waste. Renew Energy 33:726-734. https://doi.org/https://doi.org/10.1016/j.renene.2007.05.001

8. Murto M, Björnsson L, Mattiasson B (2004) Impact of food industrial waste on anaerobic co-digestion of sewage sludge and pig manure. J Environ Manage 70:101-107. https://doi.org/https://doi.org/10.1016/j.jenvman.2003.11.001

9. Arregui Arellano MJ, Alcívar M, Indelira M (2018) Evaluación de bioabonos obtenidos a partir de residuos animales provenientes del Camal Municipal de Guaranda.

10. Castro Gómez ME, Vinueza Armas MJ (2012) Manual para el Manejo Adecuado de los Residuos Sólidos Generados en el Camal Municipal de Riobamba

11. Valta K, Kosanovic T, Malamis D, et al (2015) Overview of water usage and wastewater management in the food and beverage industry. Desalin Water Treat 53:3335-3347. https://doi.org/10.1080/19443994.2014.934100

12. Federation WE, Association APH (2005) Standard methods for the examination 
13. Solarte Toro JC, Mariscal Moreno JP, Aristizábal Zuluaga BH (2017) Evaluación de la digestión y co-digestión anaerobia de residuos de comida y de poda en bioreactores a escala laboratorio. Rev Ion 30:105-116

15. Pellera F-M, Gidarakos E (2016) Effect of substrate to inoculum ratio and

14. Herrmann A, Rath J (2012) Biogas Production from Maize: Current State, Challenges, and Prospects. 1. Methane Yield Potential. BioEnergy Res 5:10271042. https://doi.org/10.1007/s12155-012-9202-6 inoculum type on the biochemical methane potential of solid agroindustrial waste. J Environ Chem Eng 4:3217-3229. https://doi.org/https://doi.org/10.1016/j.jece.2016.05.026

16. Li Y, Zhang R, Chen C, et al (2013) Biogas production from co-digestion of corn stover and chicken manure under anaerobic wet, hemi-solid, and solid state conditions. Bioresour Technol 149:406-412. https://doi.org/10.1016/j.biortech.2013.09.091

17. Nielfa A, Cano R, Fdz-Polanco M (2015) Theoretical methane production generated by the co-digestion of organic fraction municipal solid waste and biological sludge. Biotechnol Reports 5:14-21. https://doi.org/https://doi.org/10.1016/j.btre.2014.10.005

18. Liu C, Wang J, Ji X, et al (2016) The biomethane producing potential in China: A theoretical and practical estimation. Chinese J Chem Eng 24:920-928. https://doi.org/https://doi.org/10.1016/j.cjche.2015.12.025

19. Maletić S, Murenji S, Agbaba J, et al (2018) Potential for anaerobic treatment of polluted sediment. J Environ Manage 214:9-16. https://doi.org/https://doi.org/10.1016/j.jenvman.2018.02.029

20. Zhao C, Yan H, Liu Y, et al (2016) Bio-energy conversion performance, biodegradability, and kinetic analysis of different fruit residues during discontinuous anaerobic digestion. Waste Manag 52:295-301. https://doi.org/https://doi.org/10.1016/j.wasman.2016.03.028

21. Shen J, Zheng Q, Zhang R, et al (2019) Co-pretreatment of wheat straw by potassium hydroxide and calcium hydroxide: Methane production, economics, and energy potential analysis. J Environ Manage 236:720-726. https://doi.org/https://doi.org/10.1016/j.jenvman.2019.01.046

22. Castro-Molano L del P, Escalante-Hernández H, Lambis-Benítez LE, MarínBatista JD (2018) Synergistic effects in anaerobic codigestion of chicken manure with industrial wastes . DYNA 85:135-141

23. Pramanik SK, Suja FB, Porhemmat M, Pramanik BK (2019) Performance and 
Kinetic Model of a Single-Stage Anaerobic Digestion System Operated at Different Successive Operating Stages for the Treatment of Food Waste. Process. 7

24. Zahan Z, Othman MZ, Muster TH (2018) Anaerobic digestion/co-digestion kinetic potentials of different agro-industrial wastes: A comparative batch study for C/N optimisation. Waste Manag 71:663-674. https://doi.org/https://doi.org/10.1016/j.wasman.2017.08.014

25. Donoso-Bravo A, Pérez-Elvira SI, Fdz-Polanco F (2010) Application of simplified models for anaerobic biodegradability tests. Evaluation of pretreatment processes. Chem Eng J 160:607-614. https://doi.org/https://doi.org/10.1016/j.cej.2010.03.082

26. Lay J-J, Li Y-Y, Noike T (1997) Influences of $\mathrm{pH}$ and moisture content on the methane production in high-solids sludge digestion. Water Res 31:1518-1524. https://doi.org/https://doi.org/10.1016/S0043-1354(96)00413-7

27. Li L, Kong X, Yang F, et al (2012) Biogas Production Potential and Kinetics of Microwave and Conventional Thermal Pretreatment of Grass. Appl Biochem Biotechnol 166:1183-1191. https://doi.org/10.1007/s12010-011-9503-9

28. Pitt RE, Cross TL, Pell AN, et al (1999) Use of in vitro gas production models in ruminal kinetics. Math Biosci 159:145-163. https://doi.org/10.1016/S0025$\underline{\text { 5564(99)00020-6 }}$

29. Alvarez R, Lidén G (2008) Anaerobic co-digestion of aquatic flora and quinoa with manures from Bolivian Altiplano. Waste Manag 28:1933-1940. https://doi.org/https://doi.org/10.1016/j.wasman.2007.11.002

30. Sun J, Li Z, Zhou X, et al (2019) Investigation on methane yield of wheat husk anaerobic digestion and its enhancement effect by liquid digestate pretreatment. Anaerobe 59:92-99. https://doi.org/https://doi.org/10.1016/j.anaerobe.2019.05.009

31. Seppälä M, Laine A, Rintala J (2013) Screening of novel plants for biogas production in northern conditions. Bioresour Technol 139:355-362. https://doi.org/https://doi.org/10.1016/j.biortech.2013.04.014

32. Pab $>$ Pereira CP (2009) Anaerobic digestion in sustainable biomass chains. s.n.]

33. Marchaim U (1992) Biogas processes for sustainable development. Food \& Agriculture Org.

34. Sánchez A (2007) A kinetic analysis of solid waste composting at optimal conditions. Waste Manag 27:854-855

35. Fernández J, Pérez M, Romero LI (2008) Effect of substrate concentration on dry 
mesophilic anaerobic digestion of organic fraction of municipal solid waste (OFMSW). Bioresour Technol 99:6075-6080. https://doi.org/https://doi.org/10.1016/j.biortech.2007.12.048

36. Pagés-Díaz J, Westman J, Taherzadeh MJ, et al (2015) Semi-continuous codigestion of solid cattle slaughterhouse wastes with other waste streams: Interactions within the mixtures and methanogenic community structure. Chem Eng J 273:28-36. https://doi.org/https://doi.org/10.1016/j.cej.2015.03.049

37. Pagés-Díaz J, Pereda-Reyes I, Taherzadeh MJ, et al (2014) Anaerobic codigestion of solid slaughterhouse wastes with agro-residues: Synergistic and antagonistic interactions determined in batch digestion assays. Chem Eng J 245:89-98. https://doi.org/https://doi.org/10.1016/j.cej.2014.02.008

38. Pagés-Díaz J, Sárvári-Horváth I, Pérez-Olmo J, Pereda-Reyes I (2013) Codigestion of bovine slaughterhouse wastes, cow manure, various crops and municipal solid waste at thermophilic conditions: a comparison with specific case running at mesophilic conditions. Water Sci Technol 67:989-995. https://doi.org/10.2166/wst.2013.647

39. Pagés-Díaz J, Pereda Reyes I, Lundin M, Sárvári Horváth I (2011) Co-digestion of different waste mixtures from agro-industrial activities: Kinetic evaluation and synergetic effects. Bioresour Technol 102:10834-10840. https://doi.org/https://doi.org/10.1016/j.biortech.2011.09.031

40. Cuetos MJ, Gómez X, Otero M, Morán A (2008) Anaerobic digestion of solid slaughterhouse waste (SHW) at laboratory scale: Influence of co-digestion with the organic fraction of municipal solid waste (OFMSW). Biochem Eng J 40:99106. https://doi.org/https://doi.org/10.1016/j.bej.2007.11.019

41. Rosenwinkel K-H, Meyer H (1999) Anaerobic treatment of slaughterhouse residues in municipal digesters. Water Sci Technol 40:101-111. https://doi.org/https://doi.org/10.1016/S0273-1223(99)00369-8

42. Borowski S (2015) Co-digestion of the hydromechanically separated organic fraction of municipal solid waste with sewage sludge. J Environ Manage 147:8794. https://doi.org/https://doi.org/10.1016/j.jenvman.2014.09.013

43. Bouallagui H, Ben Cheikh R, Marouani L, Hamdi M (2003) Mesophilic biogas production from fruit and vegetable waste in a tubular digester. Bioresour Technol 86:85-89. https://doi.org/https://doi.org/10.1016/S0960-8524(02)000974

44. Scano EA, Asquer C, Pistis A, et al (2014) Biogas from anaerobic digestion of fruit and vegetable wastes: Experimental results on pilot-scale and preliminary performance evaluation of a full-scale power plant. Energy Convers Manag 77:22-30. https://doi.org/https://doi.org/10.1016/j.enconman.2013.09.004 
45. Lin J, Zuo J, Gan L, et al (2011) Effects of mixture ratio on anaerobic codigestion with fruit and vegetable waste and food waste of China. J Environ Sci 23:1403-1408

46. BIRCH CPD (1999) A New Generalized Logistic Sigmoid Growth Equation Compared with the Richards Growth Equation. Ann Bot 83:713-723. https://doi.org/https://doi.org/10.1006/anbo.1999.0877

47. Ware A, Power N (2017) Modelling methane production kinetics of complex poultry slaughterhouse wastes using sigmoidal growth functions. Renew Energy 104:50-59. https://doi.org/https://doi.org/10.1016/j.renene.2016.11.045

48. Patil JH, Raj MA, Muralidhara PL, et al (2012) Kinetics of anaerobic digestion of water hyacinth using poultry litter as inoculum. Int J Environ Sci Dev 3:94

49. Raposo F, Borja R, Martín MA, et al (2009) Influence of inoculum-substrate ratio on the anaerobic digestion of sunflower oil cake in batch mode: Process stability and kinetic evaluation. Chem Eng J 149:70-77. https://doi.org/https://doi.org/10.1016/j.cej.2008.10.001

50. Esposito G, Frunzo L, Liotta F, et al (2012) Bio-methane potential tests to measure the biogas production from the digestion and co-digestion of complex organic substrates. Open Environ Eng J 5:

51. Kafle GK, Kim SH, Sung KI (2013) Ensiling of fish industry waste for biogas production: A lab scale evaluation of biochemical methane potential (BMP) and kinetics. Bioresour Technol 127:326-336. https://doi.org/https://doi.org/10.1016/j.biortech.2012.09.032

52. Song H, Clarke WP (2009) Cellulose hydrolysis by a methanogenic culture enriched from landfill waste in a semi-continuous reactor. Bioresour Technol 100:1268-1273. https://doi.org/https://doi.org/10.1016/j.biortech.2008.08.029

53. Hu Z-H, Yu H-Q (2005) Application of rumen microorganisms for enhanced anaerobic fermentation of corn stover. Process Biochem 40:2371-2377. https://doi.org/https://doi.org/10.1016/j.procbio.2004.09.021

54. Fernández-Rodríguez MJ, de la Lama-Calvente D, Jiménez-Rodríguez A, et al (2019) Anaerobic co-digestion of olive mill solid waste and microalga Scenedesmus quadricauda: effect of different carbon to nitrogen ratios on process performance and kinetics. J Appl Phycol 31:3583-3591. https://doi.org/10.1007/s10811-019-01858-x

55. Solé-Bundó M, Salvadó H, Passos F, et al (2018) Strategies to optimize microalgae conversion to biogas: co-digestion, pretreatment and hydraulic retention time. Molecules 23:2096

56. Zhang R, El-Mashad HM, Hartman K, et al (2007) Characterization of food 
waste as feedstock for anaerobic digestion. Bioresour Technol 98:929-935. https://doi.org/https://doi.org/10.1016/j.biortech.2006.02.039

57. Meng Y, Li S, Yuan H, et al (2015) Evaluating biomethane production from anaerobic mono- and co-digestion of food waste and floatable oil (FO) skimmed from food waste. Bioresour Technol 185:7-13. https://doi.org/https://doi.org/10.1016/j.biortech.2015.02.036

58. Bong CPC, Lim LY, Lee CT, et al (2018) The characterisation and treatment of food waste for improvement of biogas production during anaerobic digestion - A review. J Clean Prod 172:1545-1558. https://doi.org/https://doi.org/10.1016/j.jclepro.2017.10.199

59. Hosseini Koupaie E, Azizi A, Bazyar Lakeh AA, et al (2019) Comparison of liquid and dewatered digestate as inoculum for anaerobic digestion of organic solid wastes. Waste Manag 87:228-236. https://doi.org/https://doi.org/10.1016/j.wasman.2019.02.014

60. Remigi EU, Buckley CA (2006) Co-digestion of High-strength/toxic Organic Effluents in Anaerobic Digesters at Wastewater Treatment Works. Water Research Commission

61. Vivekanand V, Mulat DG, Eijsink VGH, Horn SJ (2018) Synergistic effects of anaerobic co-digestion of whey, manure and fish ensilage. Bioresour Technol 249:35-41. https://doi.org/https://doi.org/10.1016/j.biortech.2017.09.169

62. Macias-Corral M, Samani Z, Hanson A, et al (2008) Anaerobic digestion of municipal solid waste and agricultural waste and the effect of co-digestion with dairy cow manure. Bioresour Technol 99:8288-8293. https://doi.org/https://doi.org/10.1016/j.biortech.2008.03.057

63. Deppenmeier U, Müller V, Gottschalk G (1996) Pathways of energy conservation in methanogenic archaea. Arch Microbiol 165:149-163

64. Labatut RA, Angenent LT, Scott NR (2011) Biochemical methane potential and biodegradability of complex organic substrates. Bioresour Technol 102:22552264. https://doi.org/https://doi.org/10.1016/j.biortech.2010.10.035

65. Tufaner F, Avşar Y (2016) Effects of co-substrate on biogas production from cattle manure: a review. Int J Environ Sci Technol 13:2303-2312. https://doi.org/10.1007/s13762-016-1069-1

66. Naik S, Goud V V, Rout PK, et al (2010) Characterization of Canadian biomass for alternative renewable biofuel. Renew Energy 35:1624-1631. https://doi.org/https://doi.org/10.1016/j.renene.2009.08.033

67. Zhang C, Xiao G, Peng L, et al (2013) The anaerobic co-digestion of food waste and cattle manure. Bioresour Technol 129:170-176. 
https://doi.org/10.1016/j.biortech.2012.10.138

750

751

752

753

754

755

756

757

758

759

760

761

762

763

764

765

766

767

768

769

770

771

772

773

774

775

776

777

778

779

780

781

782

783

784

785

68. Srivastava G, Kumar V, Tiwari R, et al (2020) Anaerobic co-digestion of defatted microalgae residue and rice straw as an emerging trend for waste utilization and sustainable biorefinery development. Biomass Convers Biorefinery. https://doi.org/10.1007/s13399-020-00736-8

69. Matheri AN, Ndiweni SN, Belaid M, et al (2017) Optimising biogas production from anaerobic co-digestion of chicken manure and organic fraction of municipal solid waste. Renew Sustain Energy Rev 80:756-764. https://doi.org/https://doi.org/10.1016/j.rser.2017.05.068

70. Mojapelo N, Muzenda E, Kigozi R, Aboyade AO (2014) Bio-methane potential of the organic fraction of municipal solid waste. Acad edu

71. Kubaska M, Sedlacek S, Bodik I, Kissova B (2010) Food waste as biodegradable substrates for biogas production. In: Proceedings: 37th International Conference of SSCHE May. p 2010

72. Salminen E, Rintala J, Lokshina LY, Vavilin VA (2000) Anaerobic batch degradation of solid poultry slaughterhouse waste. Water Sci Technol 41:33-41. https://doi.org/10.2166/wst.2000.0053

73. Li Y, Zhang R, Liu G, et al (2013) Comparison of methane production potential, biodegradability, and kinetics of different organic substrates. Bioresour Technol 149:565-569. https://doi.org/https://doi.org/10.1016/j.biortech.2013.09.063

74. Mussgnug JH, Klassen V, Schlüter A, Kruse O (2010) Microalgae as substrates for fermentative biogas production in a combined biorefinery concept. $\mathrm{J}$ Biotechnol 150:51-56. https://doi.org/https://doi.org/10.1016/j.jbiotec.2010.07.030

75. Velázquez-Martí B, Meneses O, Gaibor J, Niño Z (2018) Review of Mathematical Models for the Anaerobic Digestion Process

76. Raposo F, Fernández-Cegrí V, De la Rubia MA, et al (2011) Biochemical methane potential (BMP) of solid organic substrates: evaluation of anaerobic biodegradability using data from an international interlaboratory study. J Chem Technol Biotechnol 86:1088-1098. https://doi.org/10.1002/jctb.2622

77. Herrmann A, Rath J (2012) Biogas Production from Maize: Current State, Challenges, and Prospects. 1. Methane Yield Potential. BioEnergy Res 5:10271042. https://doi.org/10.1007/s12155-012-9202-6

78. Triolo JM, Sommer SG, Møller HB, et al (2011) A new algorithm to characterize biodegradability of biomass during anaerobic digestion: Influence of lignin concentration on methane production potential. Bioresour Technol 102:93959402. https://doi.org/https://doi.org/10.1016/j.biortech.2011.07.026 
79. Chen Y, Cheng JJ, Creamer KS (2008) Inhibition of anaerobic digestion process: A review. Bioresour Technol 99:4044-4064. https://doi.org/https://doi.org/10.1016/j.biortech.2007.01.057

80. Dima AD, Mateescu C, Parvulescu OC, et al (2019) Theoretical and Experimental Results on the Recovery of Potato Processing Residuals by Anaerobic Digestion. Rev Chim 70:2524-2529

81. Altaş L (2009) Inhibitory effect of heavy metals on methane-producing anaerobic granular sludge. J Hazard Mater 162:1551-1556. https://doi.org/https://doi.org/10.1016/j.jhazmat.2008.06.048

82. Abudi ZN, Hu Z, Abood AR, et al (2020) Effects of Alkali Pre-treatment, Total Solid Content, Substrate to Inoculum Ratio, and $\mathrm{pH}$ on Biogas Production from Anaerobic Digestion of Mango Leaves. Waste and Biomass Valorization 11:887897. https://doi.org/10.1007/s12649-018-0437-0

83. Hernández-Fydrych VC, Benítez-Olivares G, Meraz-Rodríguez MA, et al (2019) Methane production kinetics of pretreated slaughterhouse wastewater. Biomass and Bioenergy 130:105385. https://doi.org/https://doi.org/10.1016/j.biombioe.2019.105385

84. Vieira S, Hoffmann R (1977) Comparison of the Logistic and the Gompertz Growth Functions Considering Additive and Multiplicative Error Terms. J R Stat Soc Ser C (Applied Stat 26:143-148. https://doi.org/10.2307/2347021

85. El-Mashad HM (2013) Kinetics of methane production from the codigestion of switchgrass and Spirulina platensis algae. Bioresour Technol 132:305-312. https://doi.org/https://doi.org/10.1016/j.biortech.2012.12.183

86. Kafle GK, Chen L (2016) Comparison on batch anaerobic digestion of five different livestock manures and prediction of biochemical methane potential (BMP) using different statistical models. Waste Manag 48:492-502. https://doi.org/https://doi.org/10.1016/j.wasman.2015.10.021 


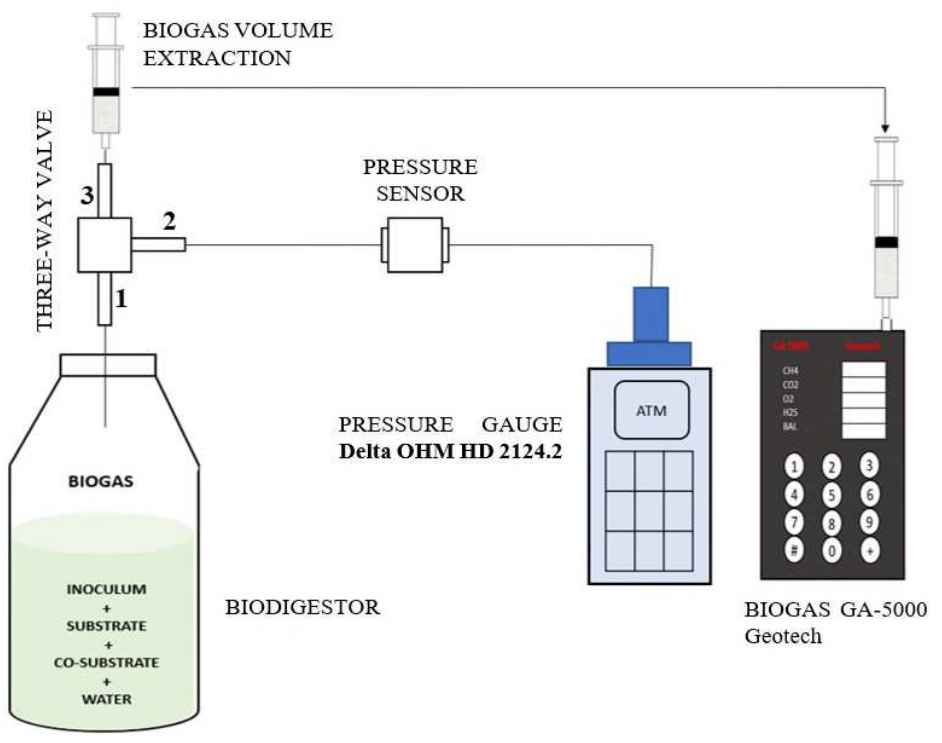

815 Figure 1. Manometric determination of the BMP of the co-digestion of slaughterhouse residues (RM) with lignocellulosic residues of agricultural origin 

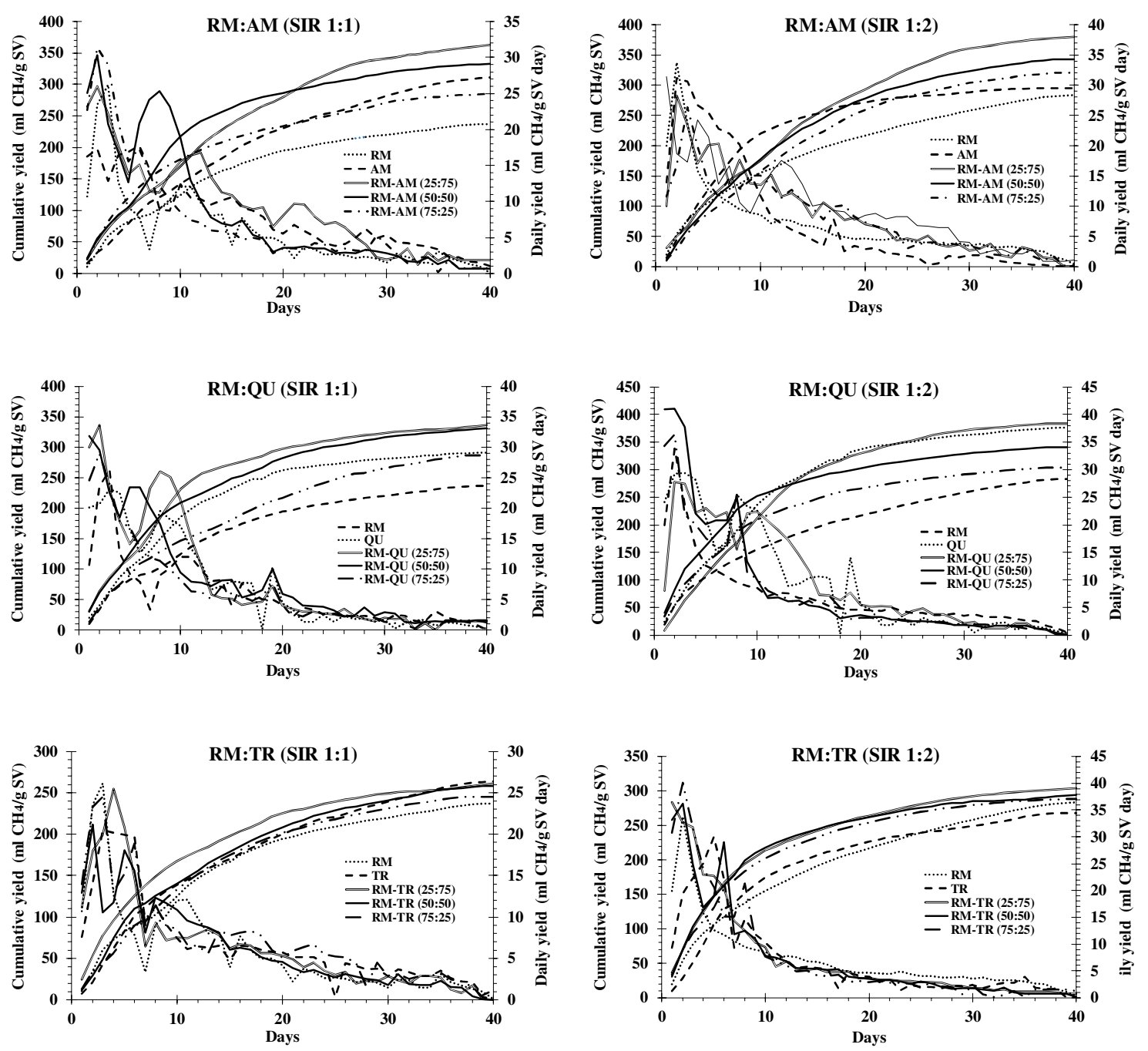

818

819

Figure 2. Daily and cumulative methane production for RM co-digestion for both SIR 1:1 and 1:2 


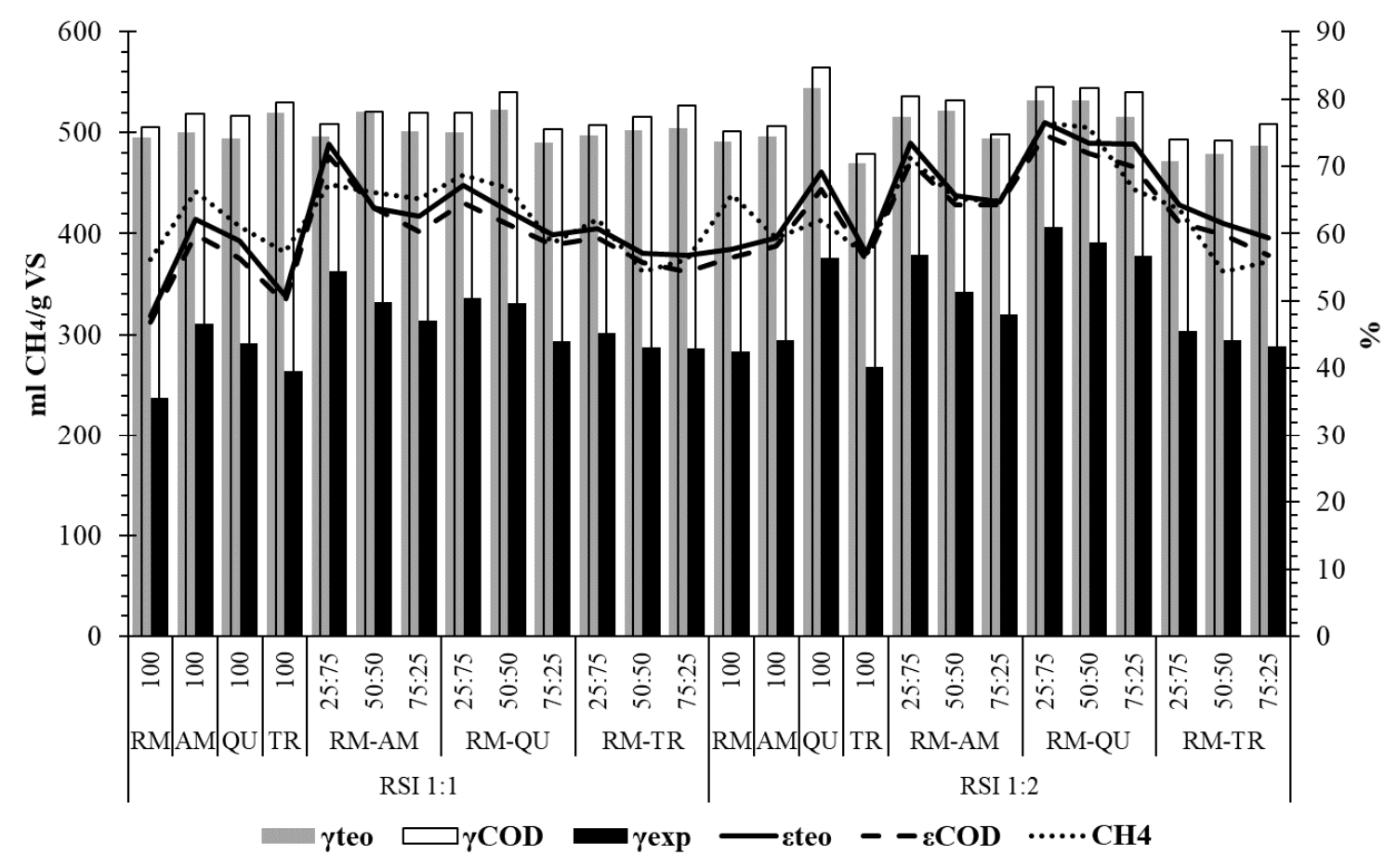

822 Figure 3. $\gamma_{\text {teo }}$ : Theoretical maximum methane yield based on elementary analysis, $\gamma_{\text {CoD: }}$ Theoretical 823 maximum methane yield based on CODt, $\boldsymbol{\varepsilon}_{\text {teo: }}$ biodegradability based on $\gamma_{\text {teo, }}, \boldsymbol{\varepsilon}_{\mathbf{C O D}}$ : biodegradability based 824 on $\mathrm{CODt}, \mathrm{CH}_{4}$ : Percentage of methane from the biogas obtained. 

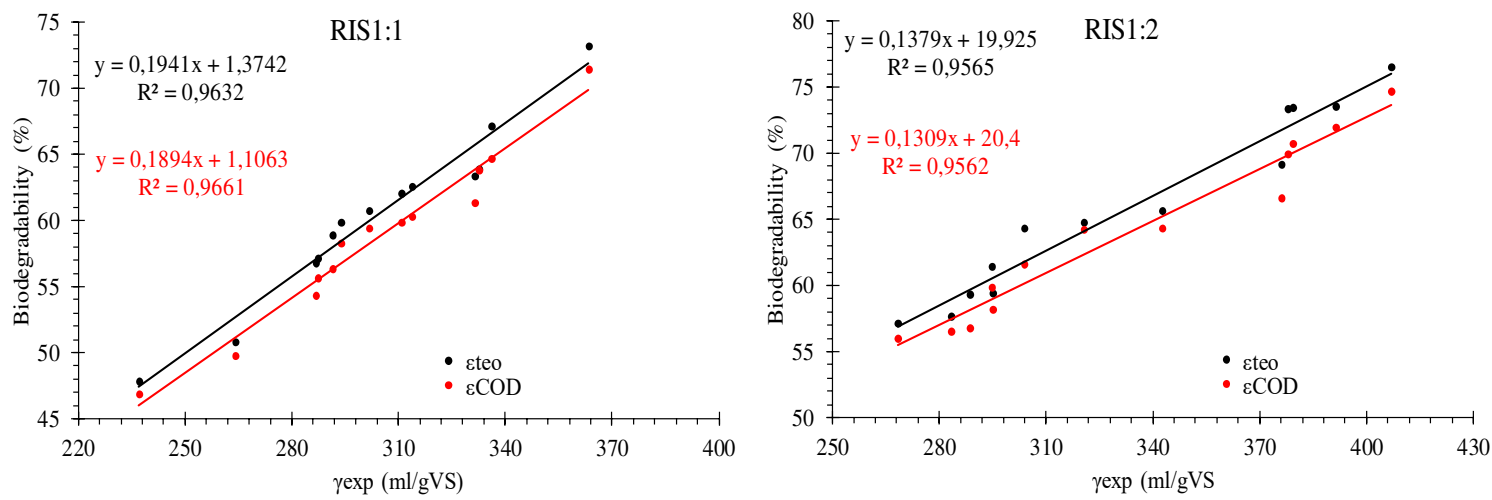

827 Figure 4. Effect of experimental performance $\gamma_{\exp }$ on biodegradability: $\varepsilon_{\text {teo }}$ : biodegradability based on $\gamma_{\text {teo, }}$ $\varepsilon_{\mathrm{COD}}$ : biodegradability based on CODt. 
Table 1. Composition of raw materials used in BMP tests.

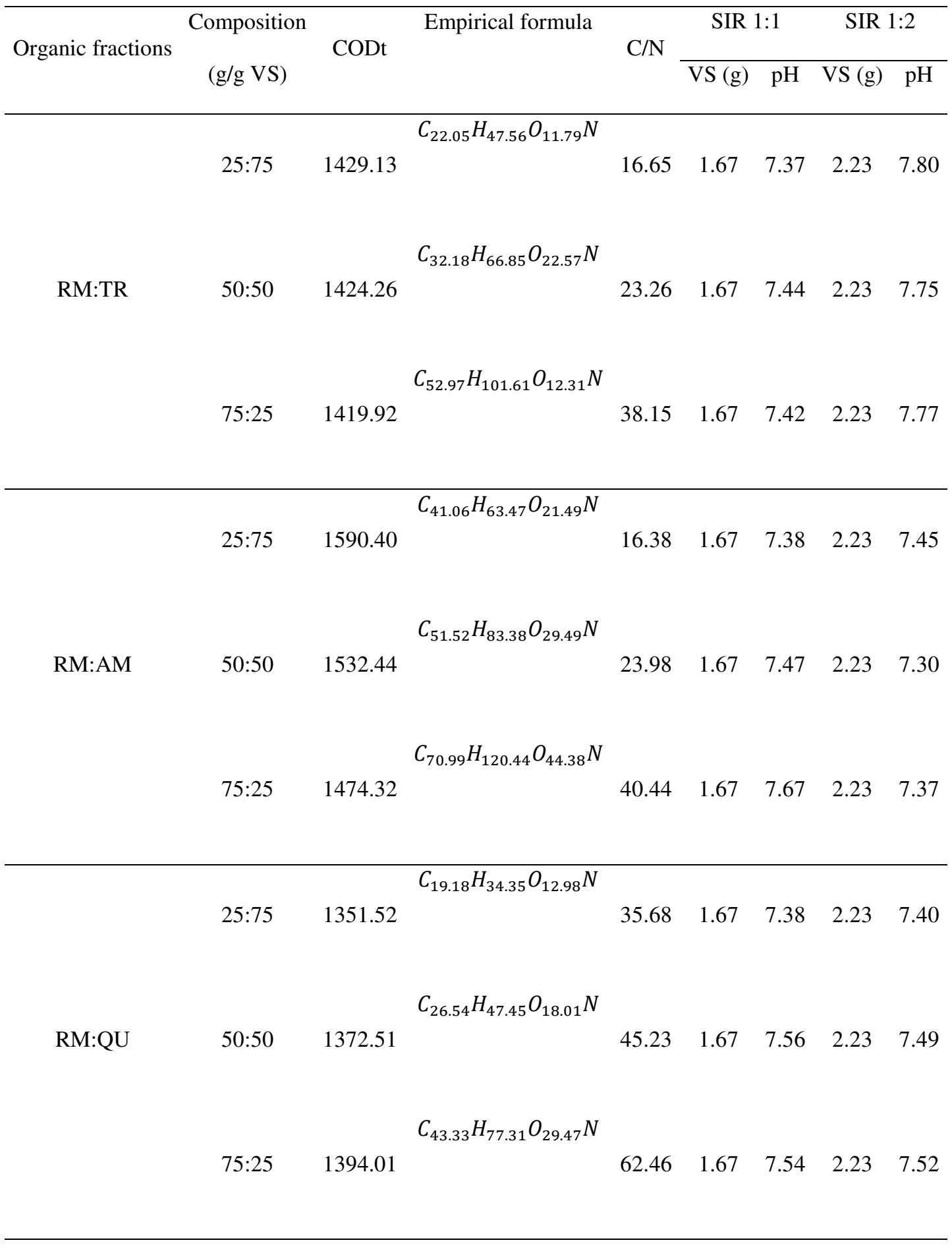




\begin{tabular}{lcccccc}
\hline Parameters & Units & RM & AM & QU & TR & IN \\
\hline TS & $\%$ & $9.6(1.3)$ & $88.2(0.1)$ & $87.0(0.1)$ & $92.6(0.1)$ & $3.9(0.1)$ \\
VS & $\%$ & $6.8(0.8)$ & $65.9(0.8)$ & $50.8(0.7)$ & $71.5(0.7)$ & $2.3(0.7)$ \\
VS/TS & - & 0.70 & 0.75 & 0.58 & 0.77 & 0.59 \\
Ash & $\%$ & $12.8(0.2)$ & $8.4(0.1)$ & $30.3(1.4)$ & $11.8(0.1)$ & $55.6(0.2)$ \\
$\mathbf{N}$ & $\%$ & $0.4(0.1)$ & $3.3(0.9)$ & $2.2(0.9)$ & $1.7(0.7)$ & $3.4(0.1)$ \\
$\mathbf{C}$ & $\%$ & $42.2(1.1)$ & $42.9(1.9)$ & $30.7(1.7)$ & $48.9(1.6)$ & $25.0(1.2)$ \\
$\mathbf{H}$ & $\%$ & $6.3(0.9)$ & $6.5(0.8)$ & $6.4(0.9)$ & $6.1(0.5)$ & $2.1(0.1)$ \\
$\mathbf{O}$ & $\%$ & $38.3(1.1)$ & $38.6(1.9)$ & $29.8(1.7)$ & $31.1(1.6)$ & $12.9(1.2)$ \\
$\mathbf{S}$ & $\%$ & $0.0(0.0)$ & $0.2(0.0)$ & $0.6(0.1)$ & $0.5(0.0)$ & $0.7(0.0)$ \\
$\mathbf{C} / \mathbf{N}$ & - & $101.9(0.9)$ & $12.9(0.8)$ & $12.0(0.9)$ & $29.6(0.8)$ & $7.5(0.7)$
\end{tabular}


Table 3. Kinetic parameters of slaughterhouse waste BMP tests SIR (1:1).

\begin{tabular}{|c|c|c|c|c|c|c|c|c|c|c|c|c|c|c|c|c|}
\hline \multirow{2}{*}{ Model } & \multirow{2}{*}{ Parameters } & \multicolumn{5}{|c|}{ RM-AM } & \multicolumn{5}{|c|}{ RM-QU } & \multicolumn{5}{|c|}{ RM-TR } \\
\hline & & $0: 100$ & $25: 75$ & 50:50 & $75: 25$ & 100:0 & 0:100 & $25: 75$ & 50:50 & $75: 25$ & 100:0 & 0:100 & $25: 75$ & 50:50 & $75: 25$ & 100:0 \\
\hline \multirow{5}{*}{$\begin{array}{l}\text { Modified } \\
\text { Gompertz }\end{array}$} & $\mathbf{M}_{\mathbf{e}}$ & 317,47 & 371,6 & 323,5 & 279,4 & 235,36 & 286,540 & 326,6 & 325,5 & 256,1 & 235,36 & 262,500 & 257,1 & 244,0 & 295,3 & 235,36 \\
\hline & $v_{\max }$ & 11,96 & 15,13 & 19,90 & 13,34 & 10,63 & 17,820 & 21,19 & 16,58 & 13,02 & 10,63 & 10,600 & 11,41 & 11,75 & 10,80 & 10,63 \\
\hline & $\mathbf{t}_{\text {lag }}$ & $-1,40$ & $-1,31$ & $-0,64$ & $-3,32$ & $-1,89$ & $-0,460$ & $-0,78$ & $-2,34$ & $-2,89$ & $-1,89$ & $-2,090$ & $-2,11$ & $-1,02$ & $-2,79$ & $-1,89$ \\
\hline & $\mathbf{R}^{2}$ & 0,994 & 0,999 & 0,996 & 0,989 & 0,992 & 0,997 & 0,997 & 0,995 & 0,994 & 0,992 & 0,980 & 0,993 & 0,998 & 0,995 & 0,992 \\
\hline & RMSE & 6,53 & 4,80 & 7,40 & 9,99 & 5,56 & 4,09 & 6,85 & 8,22 & 6,70 & 5,56 & 9,70 & 8,02 & 4,69 & 7,70 & 5,56 \\
\hline \multirow{5}{*}{ Transfer } & $\mathbf{M}_{\mathbf{e}}$ & 358,38 & 411,1 & 320,12 & 288,6 & 250,32 & 297,510 & 337,6 & 328,4 & 263,9 & 250,32 & 235,360 & 271,5 & 260,4 & 322,8 & 250,32 \\
\hline & $v_{\max }$ & 18,58 & 23,83 & 24,14 & 25,45 & 18,16 & 30,520 & 36,83 & 28,13 & 24,66 & 18,16 & 10,630 & 20,11 & 19,53 & 18,03 & 18,16 \\
\hline & $\mathbf{t}_{\text {lag }}$ & 0,13 & 0,09 & 0,01 & $-0,68$ & $-0,08$ & 0,640 & 0,38 & $-0,38$ & $-0,54$ & $-0,08$ & $-1,890$ & 0,01 & 0,42 & $-0,53$ & $-0,08$ \\
\hline & $\mathbf{R}^{2}$ & 0,999 & 0,999 & 0,998 & 0,996 & 0,996 & 0,997 & 0,997 & 0,998 & 0,999 & 0,996 & 0,990 & 0,998 & 0,999 & 0,999 & 0,996 \\
\hline & RMSE & 1,96 & 5,40 & 5,48 & 6,04 & 3,76 & 4,06 & 6,74 & 4,12 & 3,13 & 3,76 & 4,08 & 4,05 & 1,64 & 4,07 & 3,76 \\
\hline \multirow{5}{*}{$\begin{array}{l}\text { Logistic } \\
\text { equation }\end{array}$} & $\mathbf{M}_{\mathrm{e}}$ & 304,86 & 358,9 & 318,2 & 275,2 & 229,44 & 282,320 & 321,9 & 320,5 & 252,5 & 229,44 & 255,450 & 251,4 & 238,2 & 285,3 & 229,44 \\
\hline & $v_{\max }$ & 11,46 & 14,50 & 18,65 & 11,68 & 9,94 & 16,610 & 19,79 & 14,81 & 11,48 & 9,94 & 9,740 & 10,42 & 11,00 & 10,10 & 9,94 \\
\hline & $\mathbf{t}_{\text {lag }}$ & $-1,48$ & $-1,34$ & $-0,85$ & $-4,50$ & $-2,23$ & $-0,660$ & $-1,00$ & $-3,17$ & $-3,88$ & $-2,23$ & $-2,710$ & $-2,73$ & $-1,29$ & $-3,24$ & $-2,23$ \\
\hline & $\mathbf{R}^{2}$ & 0,986 & 0,997 & 0,992 & 0,982 & 0,985 & 0,990 & 0,993 & 0,990 & 0,989 & 0,985 & 0,970 & 0,987 & 0,993 & 0,991 & 0,985 \\
\hline & RMSE & 10,19 & 8,20 & 10,86 & 12,64 & 7,57 & 7,49 & 9,74 & 11,69 & 9,10 & 7,57 & 12,52 & 10,61 & 7,80 & 10,26 & 7,57 \\
\hline \multirow{5}{*}{ Cone } & $\mathbf{M}_{\mathrm{e}}$ & 454,47 & 496,6 & 363,9 & 356,8 & 304,65 & 318,930 & 363,6 & 396,0 & 314,7 & 304,65 & 361,620 & 333,2 & 297,1 & 454,0 & 304,65 \\
\hline & $\mathbf{k}$ & 0,05 & 0,06 & 0,12 & 0,10 & 0,08 & 0,120 & 0,14 & 0,11 & 0,11 & 0,08 & 0,060 & 0,08 & 0,09 & 0,05 & 0,08 \\
\hline & $\mathbf{n}$ & 1,14 & 1,20 & 1,49 & 1,01 & 1,14 & 1,550 & 1,49 & 1,15 & 1,07 & 1,14 & 1,090 & 1,12 & 1,32 & 0,97 & 1,14 \\
\hline & $\mathbf{R}^{2}$ & 0,999 & 0,997 & 0,992 & 0,982 & 0,995 & 0,997 & 0,993 & 0,990 & 0,989 & 0,995 & 0,996 & 0,987 & 0,993 & 0,991 & 0,995 \\
\hline & RMSE & 2,04 & 6,45 & 5,71 & 3,16 & 4,17 & 4,24 & 6,92 & 2,93 & 2,11 & 4,17 & 4,23 & 3,50 & 1,75 & 3,53 & 4,17 \\
\hline \multirow{6}{*}{$\begin{array}{l}\text { Modified } \\
\text { Richards }\end{array}$} & $\mathbf{M}_{\mathbf{e}}$ & 317,41 & 371,39 & 323,44 & 279,60 & 235,47 & 286,640 & 326,44 & 325,24 & 258,08 & 235,47 & 263,390 & 257,47 & 243,88 & 299,19 & 235,47 \\
\hline & d & 0,01 & 0,009 & 0,005 & 0,005 & 0,01 & 0,000 & 0,005 & 0,004 & 0,005 & 0,01 & 0,000 & 0,004 & 0,005 & 0,008 & 0,01 \\
\hline & $v_{\max }$ & 13,55 & 13,76 & 9,41 & 6,56 & 12,49 & 20,950 & 9,62 & 7,27 & 6,81 & 12,49 & 9,990 & 4,51 & 6,32 & 8,16 & 12,49 \\
\hline & $\mathbf{t}_{\text {lag }}$ & $-1,42$ & $-1,32$ & $-0,63$ & $-3,37$ & $-1,92$ & $-0,510$ & $-0,78$ & $-2,31$ & $-3,09$ & $-1,92$ & $-2,230$ & $-2,19$ & $-1,02$ & $-3,02$ & $-1,92$ \\
\hline & $\mathbf{R}^{2}$ & 0,994 & 0,999 & 0,996 & 0,989 & 0,992 & 0,997 & 0,997 & 0,995 & 0,994 & 0,992 & 0,981 & 0,993 & 0,997 & 0,995 & 0,992 \\
\hline & RMSE & 6,56 & 4,83 & 7,42 & 10,00 & 5,57 & 4,11 & 6,86 & 8,24 & 6,77 & 5,57 & 9,72 & 8,04 & 4,71 & 7,80 & 5,57 \\
\hline
\end{tabular}


Table 4. Kinetic parameters of slaughterhouse waste BMP tests SIR (1:2).

\begin{tabular}{|c|c|c|c|c|c|c|c|c|c|c|c|c|c|c|c|c|}
\hline \multirow{2}{*}{ Model } & \multirow{2}{*}{ Parameters } & \multicolumn{5}{|c|}{ RM-AM } & \multicolumn{5}{|c|}{ RM-QU } & \multicolumn{5}{|c|}{ RM-TR } \\
\hline & & 0:100 & $25: 75$ & $50: 50$ & $75: 25$ & 100:0 & 0:100 & $25: 75$ & $50: 50$ & $75: 25$ & 100:0 & $0: 100$ & $25: 75$ & $50: 50$ & $75: 25$ & 100:0 \\
\hline \multirow{5}{*}{$\begin{array}{l}\text { Modified } \\
\text { Gompertz }\end{array}$} & $\mathbf{M}_{\mathrm{e}}$ & 287,60 & 393,0 & 267,4 & 238,2 & 282,46 & 370,25 & 283,6 & 252,1 & 227,9 & 282,46 & 254,65 & 323,5 & 342,6 & 379,5 & 282,46 \\
\hline & $v_{\max }$ & 23,19 & 15,36 & 15,60 & 14,10 & 8,58 & 22,57 & 19,53 & 17,06 & 13,58 & 8,58 & 16,15 & 14,79 & 16,08 & 22,27 & 8,58 \\
\hline & $\mathbf{t}_{\text {lag }}$ & $-0,24$ & $-1,62$ & $-2,89$ & $-2,62$ & $-5,96$ & $-0,49$ & $-2,03$ & $-2,08$ & $-2,21$ & $-5,96$ & $-0,80$ & $-0,44$ & $-0,80$ & 0,41 & $-5,96$ \\
\hline & $\mathbf{R}^{2}$ & 0,991 & 0,997 & 0,980 & 0,984 & 0,969 & 0,997 & 0,983 & 0,986 & 0,991 & 0,969 & 0,977 & 0,997 & 0,995 & 0,997 & 0,969 \\
\hline & RMSE & 7,07 & 5,40 & 8,52 & 6,98 & 11,39 & 5,47 & 8,42 & 6,86 & 5,19 & 11,39 & 10,15 & 5,12 & 6,78 & 6,23 & 11,39 \\
\hline \multirow{5}{*}{ Transfer } & $\mathbf{M e}_{\mathbf{e}}$ & 293,95 & 398,4 & 272,9 & 243,5 & 307,94 & 384,97 & 288,5 & 256,7 & 233,8 & 307,94 & 263,16 & 352,4 & 367,8 & 401,5 & 307,94 \\
\hline & $v_{\max }$ & 41,23 & 29,15 & 30,68 & 27,32 & 15,01 & 38,59 & 38,06 & 32,92 & 25,54 & 15,01 & 28,87 & 23,44 & 26,42 & 35,71 & 15,01 \\
\hline & $\mathbf{t}_{\text {lag }}$ & 0,77 & $-0,36$ & $-0,57$ & $-0,46$ & $-2,42$ & 0,63 & $-0,18$ & $-0,25$ & $-0,30$ & $-2,42$ & 0,66 & 0,71 & 0,59 & 1,16 & $-2,42$ \\
\hline & $\mathbf{R}^{2}$ & 0,998 & 0,997 & 0,997 & 0,998 & 0,982 & 0,997 & 0,997 & 0,998 & 0,999 & 0,982 & 0,993 & 0,999 & 0,999 & 0,998 & 0,982 \\
\hline & RMSE & 3,02 & 3,56 & 4,90 & 3,81 & 8,78 & 5,34 & 4,55 & 3,79 & 2,46 & 8,78 & 5,66 & 3,62 & 1,54 & 6,20 & 8,78 \\
\hline \multirow{5}{*}{$\begin{array}{l}\text { Logistic } \\
\text { equation }\end{array}$} & $\mathbf{M}_{\mathbf{e}}$ & 284,80 & 378,9 & 264,7 & 235,6 & 272,16 & 364,60 & 281,1 & 249,6 & 225,2 & 272,16 & 251,17 & 314,3 & 334,0 & 372,2 & 272,16 \\
\hline & $v_{\max }$ & 21,34 & 14,69 & 13,48 & 12,30 & 7,82 & 21,05 & 17,12 & 15,05 & 12,09 & 7,82 & 14,68 & 14,13 & 15,13 & 21,27 & 7,82 \\
\hline & $\mathbf{t}_{\text {lag }}$ & $-0,50$ & $-1,69$ & $-4,02$ & $-3,62$ & $-7,16$ & $-0,69$ & $-2,84$ & $-2,84$ & $-2,96$ & $-7,16$ & $-1,29$ & $-0,46$ & $-1,00$ & 0,43 & $-7,16$ \\
\hline & $\mathbf{R}^{2}$ & 0,979 & 0,996 & 0,983 & 0,986 & 0,957 & 0,990 & 0,985 & 0,987 & 0,990 & 0,957 & 0,961 & 0,995 & 0,993 & 0,995 & 0,957 \\
\hline & RMSE & 10,6 & 9,01 & 11,01 & 9,25 & 13,35 & 9,73 & 11,09 & 9,18 & 7,43 & 13,35 & 13,27 & 9,04 & 11,14 & 11,43 & 13,35 \\
\hline \multirow{5}{*}{ Cone } & $M_{e}$ & 308,30 & 544,3 & 314,1 & 278,2 & 716,77 & 414,30 & 318,3 & 284,4 & 264,8 & 716,77 & 287,83 & 397,2 & 420,2 & 423,2 & 716,77 \\
\hline & $\mathbf{k}$ & 0,17 & 0,06 & 0,15 & 0,15 & 0,01 & 0,12 & 0,18 & 0,17 & 0,14 & 0,01 & 0,13 & 0,08 & 0,08 & 0,10 & 0,01 \\
\hline & $\mathbf{n}$ & 1,67 & 1,14 & 1,10 & 1,13 & 0,66 & 1,53 & 1,24 & 1,23 & 1,19 & 0,66 & 1,43 & 1,38 & 1,33 & 1,69 & 0,66 \\
\hline & $\mathbf{R}^{2}$ & 0,999 & 0,998 & 0,999 & 0,999 & 0,991 & 0,997 & 1,000 & 0,999 & 0,999 & 0,991 & 0,996 & 0,999 & 0,999 & 0,999 & 0,991 \\
\hline & RMSE & 4,30 & 6,33 & 1,80 & 1,92 & 1,89 & 1,67 & 1,95 & 2,26 & 2,29 & 1,89 & 0,61 & 3,88 & 2,44 & 4,48 & 1,89 \\
\hline \multirow{6}{*}{$\begin{array}{l}\text { Modified } \\
\text { Richards }\end{array}$} & $M_{e}$ & 287,58 & 392,79 & 267,64 & 238,36 & 283,04 & 370,21 & 283,66 & 252,08 & 227,91 & 283,04 & 254,78 & 323,34 & 342,74 & 379,44 & 283,04 \\
\hline & d & 0,00 & 0,022 & 0,004 & 0,001 & 0,00 & 0,01 & 0,023 & 0,005 & 0,006 & 0,00 & 0,00 & 0,007 & 0,006 & 0,006 & 0,00 \\
\hline & $v_{\max }$ & 27,67 & 33,05 & 5,72 & 0,70 & 10,13 & 26,52 & 43,40 & 9,07 & 8,14 & 10,13 & 19,26 & 9,62 & 9,87 & 12,46 & 10,13 \\
\hline & $\mathbf{t}_{\text {lag }}$ & $-0,24$ & $-1,65$ & $-2,95$ & $-2,68$ & $-6,13$ & $-0,50$ & $-2,07$ & $-2,09$ & $-2,23$ & $-6,13$ & $-0,84$ & $-0,43$ & $-0,82$ & 0,41 & $-6,13$ \\
\hline & $\mathbf{R}^{2}$ & 0,991 & 0,999 & 0,990 & 0,992 & 0,969 & 0,997 & 0,991 & 0,993 & 0,995 & 0,969 & 0,978 & 0,998 & 0,997 & 0,998 & 0,969 \\
\hline & RMSE & 7,09 & 5,49 & 8,53 & 6,98 & 11,4 & 5,50 & 8,50 & 6,88 & 5,21 & 11,4 & 10,16 & 5,15 & 6,81 & 6,26 & 11,4 \\
\hline
\end{tabular}

